\title{
Four Thousand Fish
}

\author{
Jonah Johnson
}

University of Technology Sydney, Faculty of Arts and Social Sciences, PO Box 123, Ultimo NSW 2017, Australia. jonah.s.johnson@student.uts.edu.au

DOI: https://doi.org/10.5130/nesais.v4i1.1522

Four Thousand Fish, curated by Kalari (South-West NSW) woman Emily McDaniel, is an exhibition that very precisely highlights the act of participation in sharing, shaping and taking responsibility in narratives. There are multiple overlapping aspects and commentaries that this exhibition touches upon; however, for the purposes of this review I am wanting to focus on how McDaniel goes about framing and shaping narrative, particularly with a narrative that has somewhat been hidden behind a colonial front, and highlight the importance of McDaniel's telling of this story.

Around 1790, early on in the piece of British colonisation, naval Captain Arthur Phillip, Governor of NSW, was wounded in an altercation between the Eora people and the British. Journal entries by Lieutenant colonel David Collins (1804) records that Bennelong, a Wangal man, assured the Governor that the spear that wounded his shoulder was due to a misunderstanding, and is credited by the British as having deescalated the situation. The journal records, "On the tenth day after he had received the wound, his Excellency was so far recovered as to go to the place, accompanied by several officers, all armed" (Collins, D. 1804). The place referred to in this passage is that of Bennelong's and his people on the north shore of Sydney cove, bringing with them as they boast, a minute portion of a 4000-fish catch that the British colonists pulled out of Sydney Harbour. Barangaroo, wife of Bennelong, strongly opposed the practices of the colonists and Bennelong's dealings with Governor Phillip, as she and the other Eora women were the ones who oversaw Sydney Harbour, sustenance fishing and looking after the health of the cove. This is the story that Emily McDaniel is exhibiting in her installation which stood at the site of the newly renovated Barangaroo point in Nawi Cove, Sydney Harbour during the course of the 2018 Sydney Festival.

At the core of the exhibition was public participation, whereby passers-by, Sydney Festival goers, or Emily McDaniel fans were invited to carry a frozen salmon shaped block of ice to the large Nawi (Canoe) and place the fish in there. They would then take some water from the harbour and fill a mould to be frozen again. As the sun sets over Nawi Cove, the fish would melt and return back into the cove, an act that mimics that of the practices of Barangaroo and the many women before her. Packed with some extremely deep yet straightforward symbolism, McDaniel's installation reflects the story of British colonialists pulling 4000 fish out of Sydney Cove in 1790 as a gift for newly arriving British. Lieutenant-Colonel David Collins records in an account of the British colony: 
The day preceding the Governor's (Phillip) visit, the Fishing boats had the greatest success that they had been met with; near four thousand of a fish, named by the inhabitants, from its shape only, the salmon... each weighing on average about five pounds; they were issued to both Port Jackson and Rose Hill; and between thirty and forty were sent as a conciliation present to Bennelong and his party on the North Shore. (Collins 1804, p. 112)

A core theoretical approach that I want to link as being demonstrated throughout McDaniel's work is the notion of representation and colonial violence. Morris (1992) identifies that representation itself is a constitutive form of violence, and that violence itself is mediated and constituted by representation. In saying this, Morris is demonstrating that although we understand colonial frontier violence as being a series of physically violent acts (i.e. massacres), what we don't tend to look at is the sustained cultural representation that informs these acts of violence. Through framing it in such a way, we are able to develop a more comprehensive understanding of colonial violence, where cultural representations of Indigenous peoples justified the violence perpetrated against them, whilst simultaneously informing these representations. McDaniel's exhibition is something that lacks in the anxiety that is reflected through colonial narratives of Indigenous peoples that came about through the development of cultural representations of Indigenous peoples. She highlights the importance of a shared responsibility in maintaining these narratives, through participation, and almost remedies some of the scars that these cultural representations inflicted, particularly ones that have been connected to a place like Sydney Harbour.

McDaniel's exhibition also demonstrates Stanner's call for a different kind of history, where Aboriginal people are brought into the main flow of its narrative (Curthoys, A. 2008). Although Stanner's vision may not have been for art installations curated by Indigenous people, but rather a structural change in the discipline of history, McDaniel's exhibition takes Stanner's call one step further and demonstrates Indigenous truths that are truths for the whole of Australia, as they are a part of its colonial front. It is a representation of Aboriginal people being brought "into the main flow of its narrative" (Curthoys, A. 2008). Curthoys also highlights Stanner's exemplification of the multiple historians account of Australian history aligning it with 'inattention' to Aboriginal people's as a part of these historical truths. Highlighting that European practice of history is extremely political.

There is something that strikes about Emily McDaniel's Four Thousand Fish, feelings of something that is extremely fulfilling and legitimate. Every aspect of the exhibition is woven together with such purpose and precision, with her aim to bring Barangaroo as a woman to the forefront of participants' minds when entering that space and even the broader context of Sydney makes it difficult to ignore these narratives thrusting into the consciousness of Australia. There is something about the timing and context of the exhibition that brings about strong emotions, something that is perhaps a side effect of a narrative that is supposed to be in place, or a narrative that has been appropriately aligned to reflect truths that exist for many people. 


\section{References}

Collins, D., King, P.G., Bass, G., \& Collins, M. 1804, An account of the English colony in New South Wales, from its first settlement in January 1788, to August 1801: with remarks on the dispositions, customs, manners, \&c., of the native inhabitants of that country. To which are added, some particulars of New Zealand; compiled, by permission, from the mss. of Lieutenant-Governor King; and an account of a voyage performed by Captain Flinders and Mr. Bass; by which the existence of a strait separating Van Diemen's land from the continent of New Holland was ascertained. Abstracted from the journal of Mr. Bass, London, Printed for T. Cadell and W. Davies.

https://doi.org/10.5962/bhl.title.94762

Curthoys, A., 2008, 'WEH Stanner and the historians', in Hinkson, M., and Beckett, J., (eds), An Appreciation of Difference: WEH Stanner and Aboriginal Australia, Canberra, Aboriginal Studies Press, pp 233-250.

Morris, B., 1992, 'Frontier colonialism as a Culture of Terror', in Power, Knowledge and Aborigines, Bundoora, Vic., La Trobe University Press in association with the National Centre for Australian Studies, Monash University, pp 72-87.

(c) (1) (C) 2018 by the author(s). This article is distributed under the terms and conditions of the Creative Commons Attribution license (http://creativecommons.org/licenses/by-nd/4.0/). 